\title{
REMEDYING THE DEFECTS IN INDIA'S CREDIT AND INSOLVENCY FRAMEWORKS WITH ADAPTED SOLUTIONS FROM THE ANGLO-AMERICAN LEGAL SCHOLARSHIPS
}

"The only man who sticks closer to you
in adversity than a friend is a creditor."

English Proverb

\begin{abstract}
The law governing credit transactions in India is compartmentalized and concomitantly poses difficulties to contractual parties and access to credit: the overall effect of this is already being felt owing to the country's low rank on the 'getting credit' indicator of the World Bank's Ease of Doing Business Report 2020. The Insolvency and Bankruptcy Code 2016 (Code), being almost a mirror-image of the English Insolvency Act 1986, has some inherent defects that are incompatible with the local conditions vis-à-vis access to credit and business rescue. Some of these defects arguably emanate from the Code's unfair categorization of creditors into the 'operational' and 'financial' types, and the ensuing confusion as was witnessed in the Supreme Court's Home Buyers' case in 2019. Strangely, financial creditors enjoy some Code-given preferential treatments over operational creditors including the right to constitute committees of creditors in voting and confirming business rescue plans. The insolvency resolution process of the Code is incompatible with the fact that over 90\% of the companies doing business in India are SMEs and family-owned. The crushing financial weight of insolvency resolution processes is foreseen to gradually cannibalize these SMEs and cause a sharp rise in the unemployment rate. The article diagnoses a number of defects in the credit and

LLB, LLM, SJD., Associate Professor of Law, Center for International Trade and Economic Laws, O. P. Jindal Global University. I am grateful to Dr. Joseph Nwobike SAN and the two anonymous reviewers for their constructive feedback. I am grateful to Mr. Benjamin Iheme (Richland Market Grocery Inc) and Sir Oliver Iheme (Blessing's Home Health Agency) for providing me with resources which enabled me to conduct this research. Of course, the usual caveat applies; e-mail: wciheme@jgu.edu.in; williamsiheme@gmail.com
\end{abstract}


Williams C. Iheme, Remedying the Defects in India's Credit and Insolvency Frameworks...

insolvency systems of India, and proposes transplantable solutions from the English system, the U.S. Chapter 11, and Article 9 of the Uniform Commercial Code.

Key words: credit, collateral, debt, security, business rescue, insolvency, creditor, debtor, law reform.

\section{Introduction: A Glimpse of the Problems}

Henry Macleod repeats the ancient and accepted wisdom that credit is the lifeblood of market economies: ${ }^{1}$ yet according to the World Bank Ease of Doing Business Report 2020, ${ }^{2}$ India does not still rank impressively on the 'getting credit' indicator. A number of reasons ranging from law, economic, cultural, and political issues could be responsible for this; but in this paper, only the reasons bordering on the legal framework will be examined. In the author's view, the most compelling reason that inhibits sufficient access to credit in India rests on the compartmentalization of laws governing the use of movable assets to secure credit. These laws are currently sprinkled across many pieces of legislation and case law. ${ }^{3}$

The ensuing complexity therefore presents a challenge to parties entering into 'security interest ${ }^{4}$ transactions: they typically incur extra costs in legal advice in order to navigate safely through the myriad of legislation and case law. Concluding credit transactions without legal advice presents the risk that one might inadvertently leave out important requirements of law, the consequence of which is invalidation of the transaction or acquisition of a lower position in a counterparty's insolvency and liquidation. ${ }^{5}$ Unsurprisingly, India’s security interest regimes shares striking similarities

1 Macleod, H., 1876, Principles of Economical Philosophy, Longmans, Green, Reader \& Dyer, p. 481; Weston, K., 2013, Lifeblood, Liquidity, and Cash Transfusions: Beyond Metaphor in the Cultural Study of Finance, Journal of the Royal Anthropological Institute, Vol. 19, No. 1, pp. 25-26.

2 World Bank Ease of Doing Business Report, 2020 (https://www.doingbusiness.org/ en/rankings).

3 These include the Companies Act 2013, Hire purchase and equipment leasing governed by the Indian Contract Act, 1872, SARFAESI Act 2002, common law rules on conditional sale, etc.

4 A reliable definition of 'security interest' as used in this paper can be found in the decision of Browne-Wilkinson V-C in Re Paramount Airways Ltd 2 [1990] BCC 130 at 149. Similarly, Lord Scott in Smith v. Bridgend County Borough Council [2002] 1 AC 336 at 355, stated that 'a contractual right enabling a creditor to sell his debtor's goods and apply the proceeds in or towards satisfaction of the debt is a right of a security character'.

5 For Nigeria's experience prior to the reform of its security interest law in 2017, see Iheme, WC., 2016, Towards Reforming the Legal Framework for Secured Transactions in Nigeria, Springer; Gikay, A., 2017, Rethinking Ethiopian Secured Transactions Law 
with the English formal approach: thus, some of the problems encountered under English secured credit law, including those emanating from its compartmentalization as well as the existence of separate collateral registries as pointed out by Iris Chiu, ${ }^{6}$ are also profoundly visible in India. ${ }^{7}$ In fact, in the case of India, the challenges appear to be worse because it is comparably less developed, and also has a strange categorization of creditors into 'financial' and 'operational' types in the Insolvency and Bankruptcy Code, $2016 .^{8}$

Similarly, in the author's opinion, India's absent-minded transplantation of credit and insolvency laws from the English and U.S systems have resulted into the co-existence of two conflicting types of floating securities: namely, the floating charge (contained in the Companies Act 2013) ${ }^{9}$ and the U.S' kin, but hardly the equivalent, known as the floating lien (contained in the SARFESI Act 2002). ${ }^{10}$ In addition to this conflict, there are the retention of title devices: the conditional sale, hire purchase, ${ }^{11}$ equipment leasing, etc., which operate separately outside the SARFESI Act, ${ }^{12}$ governed more specifically by the Indian Contract Act 1872 and the common law. These retention of title devices generally escape the requirement of registration, unlike chattel mortgages which must be registered within 30 days after creation. ${ }^{13}$

through Comparative Perspective: Lessons from the Uniform Commercial Code of the US, Mizan Law Review, Vol. 11, No. 1, pp. 174-178.

6 Chiu-Iris, H-Y., 2006, The Legal Fabrication of Security Interests in the United Kingdom, North Carolina Journal of International Law and Commercial Regulation, Vol. 31, No. 3, 703, p. 704 (explaining the current challenges of English security interest law).

7 This prompted the statement that "despite the obvious importance of the concept of 'security interest' to the law of secured transactions, the concept continues to evade precise definition". See Ali, P., 2002, The Law of Secured Finance, Oxford, Oxford University Press, p. 15.

8 Section 3, Insolvency and Bankruptcy Code, 2016. The reason this categorization is considered a misnomer will be explained later in this paper. The equivalent of 'operational' and 'financial' credit in other systems such as Germany and France, are 'trade/ supplier' credit and 'bank' credit, respectively. I am grateful to one of the reviewers for drawing my attention to this comparison. See generally: Burkart, M., Ellingsen, T., 2004, In-kind Finance: A Theory of Trade Credit, The American Economic Review, Vol. 94, pp. 569-590; Danielson, M. G., Scott, JA., 2004, Bank Loan Availability and Trade Credit Demand, The Financial Review, Vol. 39, pp. 579-600.

9 See section 84 .

10 See the meaning of 'hypothecation' under section 2 of the SARFAESI Act, 2002.

11 The Hire Purchase Act, 1972.

12 See section 31 SARFAESI Act.

13 The Central Registry of Securitisation Asset Reconstruction and Security Interest of India (Cersai) is an online collateral registry that records security interests created on movable assets, (https://www.cersai.org.in/). 
Agreeing with professor Weir's view, the critical problem with the compartmentalized (formal) approach to securities is that financiers seeking to bypass the cost and complexities of mortgage registration, would prefer to purchase the borrower's collateral and resell to them under a conditional sale arrangement, so that the buyer or borrower's equitable possession remains subservient to the lender or seller's legal title. This superiority of the seller's title survives even in the context of a bona fide purchaser for value claim, owing to the nemo dat principle. ${ }^{14}$ This type of maneuver is a necessary byproduct of a system that formally categorizes rights into 'equitable' or 'legal' as in India and England. ${ }^{15}$

Compartmentalization of security interests used to pose enormous problem in the United States until the intervention of Grant Gilmore ${ }^{16}$ and his colleagues who reformed the system into its approach of unitary-function. The U.S functional approach system in the first half of the $20^{\text {th }}$ century, subsumed the four common law security and quasi-security devices: namely, mortgage, charge, pledge, and consensual lien, conditional sale, hire purchase, etc., into a single security interest device that is triggered to apply where a debtor has borrowed money from a lender and secured it with a personal (movable) property for which the debtor has some form of interest, whether legal or equitable. ${ }^{17}$ In agreement with the views expressed by LoPucki et al., this paper proposes that the U.S unitary-functional approach to security would be more suitable for the Indian system, mainly due to its less complicated nature, and the fact that it tends to appeal more to individuals and small businesses that are unlikely to afford legal services in concluding a complex credit transaction. ${ }^{18}$

14 Weir, T., 1996, Taking for Granted: The Ramifications of Nemo Dat, Current Legal Problems, Vol. 49, No. 1, 325-345, pp. 331-334. Also see Lord Hoffmann in Edwards v. Flightline Ltd [2003] 1 WLR at 1200.

15 Pierre, B., 1997, Classification of Property and Conceptions of Ownership in Civil and Common Law, Revue Générale de Droit, Vol. 28, No. 2, pp. 235-274, 247.

16 Gilmore, G., 1965, Security Interests in Personal Property, Boston, Little, Brown, Vol. 1, pp 288-89; McCormack, G., 2011, American Private Law Writ Large? The UNCITAL Secured Transactions Guide, The International and Comparative Law Quarterly, Vol. 60, No. 3, pp. 597-625.

17 See Harris, S. L., and Mooney Jr. C. W., 1993, The Article 9 Study Committee Report: Strong Signals and Hard Choices, Idaho Law Review, Vol. 29, 561, p. 569 ("Article 9 generally has provided a sound set of rules governing attachment, perfection, priority and enforcement of security interests in personal property.").

18 LoPucki, L. M., Abraham, A. I., Delahaye, B. P., 2013, Optimizing English and American security interests, Notre Dame Law Review, Vol. 88, 1785 at pp. 1790-1791. Also see LoPucki, L. M., 1997, The Systems Approach to Law, Cornell Law Review, Vol. 82, pp. 514-16 at 479 (describing the application of functional approach to a comparison of United States' and Canadian reorganization systems). 
Additionally, the paper examines the Indian approach to insolvency, especially as it relates to 'business rescue' and argues that due to the combination of English, U.S, and the idiosyncratic (Indian) conditions in the Insolvency and Bankruptcy Code 2016 (IBC 2016), the business rescue philosophy underlying the Indian regime has become inconsistent and confusing when compared to what 'business rescue' means in other jurisdictions, say the U.S and England. ${ }^{19}$ For instance, the IBC 2016 unapologetically shows preference for financial creditors over their operational counterparts, and protects the former's interests more than is fairly necessary. ${ }^{20}$ Similarly, in reforming the 2013 Companies Act, Indian lawmakers without any justifiable reasons, abolished the more befitting Company Voluntary Arrangement (CVA) that used to exist under the repealed 1956 Companies Act. ${ }^{21}$

Even though Schemes of Arrangement (Schemes) is left in the extant 2013 Companies Act, ${ }^{22}$ it is argued that its intrinsic lack of 'moratorium', enables dissenting creditors to disregard any proposal for corporate rescue: owing to the lack, they could fall back on their contractual rights to commence a winding up action. India's Insolvency Resolution Process, ${ }^{23}$ the equivalent of the English law-styled Administration, ${ }^{24}$ is also unbefitting for a country that is still battling with an unacceptable level of corruption. ${ }^{25}$ Even in the United Kingdom where Administration has been tested for more than three decades, courts $^{26}$ and English law scholars, ${ }^{27}$ such as professors Mulligan and Tribe, have lamented about the crush-

19 Payne, J., 2014, Debt Restructuring in English Law: Lessons from the US and the Need for Reform, University of Oxford Legal Research Paper Series (https://ssrn.com/ abstract=2321615).

20 For example, under section 21(2) IBC 2016, the committee of creditors is only composed of the financial creditors.

21 Sections 391-394, Companies Act 1956, India.

22 Section 230 Companies Act 2013, India.

23 See chapter II of the IBC 2016.

24 See Schedule B1 of the Insolvency Act 1986. Administration is an insolvency rescue process that entails the ousting of the corporate debtor's management, and replacing it with an insolvency practitioner who becomes the Administrator with full statutory powers to manage the debtor company. See Finch, V., 2009, Corporate Insolvency Law, chap. 9.

25 India currently ranks $80^{\text {th }}$ out of 180 countries in the 2019 Corruption Perception Index, (https://www.transparency.org/en/cpi/2019).

26 Mirror Group Newspapers plc v. Maxwell [1998] BCC 324.

27 Mulligan, M., Tribe, J., 2003, The Remuneration of Office Holders in Corporate Insolvency - Liquidators, Administrators and Administrative Receivers: Part 1', Insolvency Lawyer, Vol. 3 101, p. 104 (describing the decisions of Ferris, J. in Re Independent Insurance Co Ltd [2002] 2 BCLC 709 and Re Independent Insurance Co Ltd (No 2) [2003] EWHC 51 (Ch) as "ensuring that the true beneficiaries of an insolvent estate, 
ing costs of Administration and how it is functionally antithetic to the notion of business rescue, at least judging from the picture that was initially painted by the Cork Committee. This accurate sentiment is partly accentuated by the high fees being regularly charged by Administrators, ${ }^{28}$ and the fact that the IBC 2016 or the UK Insolvency Act 1986 allows Administrators a total of about 18 months period to resuscitate an insolvent company, ${ }^{29}$ thereby eliminating any incentive for an Insolvency Resolution Professional in India or an Administrator in the UK to engage in a swift resuscitation of the dying company.

Even though governments in the United Kingdom and India would hardly acknowledge the failure of the Administration system, data sufficiently show that many companies in administration eventually move to liquidation, usually after they had incurred huge extra costs in administrator's fees and expenses. ${ }^{30}$ In that case, under a proper examination, the abolished CVA under the Indian 1956 Companies Act, ${ }^{31}$ which stipulated a retention of debtor in office during a resolution process, in addition to appointment of a supervisor would have remained more befitting for India given the comparably lower cost involved, and the fact that a significant number of Indian companies are family owned: ${ }^{32}$ therefore, ousting of management would likely do more harm than good to a small company being rescued. Similarly, the author of this paper proposes that

the creditors, will have a reliable independent quantification of the office holder remuneration").

28 Mirror Group Newspapers plc v. Maxwell [1998] BCC 324, "the three accounting firms handling the administration of the Maxwell empire reported fees of nearly $£ 35$ million and the receivers to the Robert Maxwell estate, accountants Buchler Phillips, recovered $£ 1.672$ million, but their bills, together with those of solicitors Nabarro Nathanson, came to $£ 1.628$ million, leaving only $£ 44,000$ for creditors": Finch, V., 2009, Corporate Insolvency Law - Perspectives and Principles, Cambridge, Cambridge University Press, p. 186.

29 See section 12 IBC 2016; and Sch. B1, para. 76, Insolvency Act 1986. In the case of India, it is a total period of 9 months.

30 Example, see Solomons and Defty v. Cheal, Huggins and Coster [2011] EWHC 2543 (Ch), in particular para. 14, where Justice Norris noting the high fees of administrators, lamented on the ineffectiveness of administration.

31 Sections 391-394.

32 Press Trust of India, 2018, India has third highest number of family-owned businesses in the world, Business Standard, (https://www.business-standard.com/article/ current-affairs/india-has-third-highest-number-of-family-owned-businesses-in-theworld-118091400409_1.html, 14. 9. 2020) (stating that "Indian family-owned companies generated a 13.9 per cent annual average share price return since 2006 , compared to 6 per cent recorded by their non-family-owned peers, the report said." Press Trust of India, "India has third highest number of family-owned businesses in the world"). 
the U.S debtor-in-possession (DIP), ${ }^{33}$ the functional equivalent of CVA should inspire Indian lawmakers in reforming the IBC 2016. Moreover, amendments to the Insolvency Act 1986, which allegedly served as the inspirational source for the IBC 2016, provide for CVA and a moratorium for small companies: ${ }^{34}$ incidentally, most companies in India would fall under the category of the UK 'small companies' entitled to use the CVA and moratorium. India should therefore reinstate the CVA into its legal regime.

\subsection{RESEARCH QUESTIONS, METHODOLOGY \& AIM}

This paper asks and investigates a number of questions, which are:

i. Whether any material defects exist under the credit and insolvency regimes of India?

ii. Whether the Insolvency Resolution Process under the Insolvency and Bankruptcy Code and the Insolvency Resolution Professional Regulations, both of which mimic the English system of Administration, are actually befitting for India?

iii. Whether there are any transplantable solutions from the more experienced jurisdictions, for instance, the United Kingdom and United States, that can be useful in the reform of the Indian credit and insolvency regimes?

In answering these questions, the paper examines the frameworks of credit and insolvency laws of India in order to ascertain whether in reality, the provisions of the relevant credit and insolvency legislation and common law are sufficient to address the underlying critical issues. In the analytical process, it points out the inconsistencies in legal and commercial reasoning as well as some foreign but misapplied concepts that still pose difficulties in the Indian commercial setting. Further, based on the comparative analysis of the three jurisdictions: India, United Kingdom, and United States, the paper examines and ascertains what features could possibly be transplanted in adapted forms toward addressing the contemporary challenges of the Indian system.

The methodology undertaken in the research is mainly the textual analyses of black-letter laws, anecdotal evidence from the author's graduate students, opinions of scholars, and court decisions of the concerned

33 Li, K., and Wang, W., 2016, Debtor-in-Possession Financing, Loan To-Loan, and Loan to Own, Journal of Corporate Finance, Vol. 39, Issue C, 121-138, pp. 126-131.

34 Part I and Schedule A1 of the Insolvency Act 1986. 
jurisdictions. Also, where necessary, reliable quantitative data that are secondarily available are used to support the underlying claims. The primary aim of this research is to clearly present the diagnosed defects in the credit and insolvency legal frameworks of India as well as suggest some solutions, which should hopefully inspire Indian lawmakers genuinely interested in reforming and enhancing the level of effectiveness of these laws toward expanding access to credit as well as creating a fairer system of reorganization and liquidation of businesses.

Lastly, in the aftermath of the Covid-19 pandemic, access to affordable credit has become a frequently suggested solution for a quick economic recovery in India and elsewhere: as many businesses would be impacted negatively by the pandemic, the need to simplify and enhance the underlying laws of credit and insolvency to serve as the system's workhorse for economic recovery has become exigent.

\section{The Diagnosed Defects of the Credit AND Insolvency Systems IN INDIA}

\subsection{THE FIRST DIAGNOSED DEFECT: COMPARTMENTALIZATION OF THE SECURED CREDIT LAWS}

Secured credit law and insolvency law are interwoven and a reform of one invariably necessitates a reform in the other. In India, various laws govern debt repayment obligations, depending on the nature of asset of the borrower. The Transfer of Property Act 1882, governs transactions that alienate interest in immovable collateral of a borrower. Security interests created on immovable asset-collateral require to be stamped and registered/perfected as preconditions for assuming a legal status. ${ }^{35}$ Perfection (registration) converts the created interest on collateral from its equitable nature to a more enhanced senior status of legal interest. Certain documents under India's Registration Act 1908 are to be compulsorily registered in order to be valid: ${ }^{36}$ lack of registration only creates an equitable interest in them, which affects the hierarchical status in the context of insolvency and liquidation of the debtor. In fact, in the case of a corporate debtor, lack of registration of an encumbering charge entitles a corporate liquidator to disclaim the transaction from being effective against the debtor's estate. ${ }^{37}$

35 Section 32, Registration Act, 1908.

36 Section 17, Registration Act, 1908.

37 Section 77 of Companies Act, 2013. 
The SARFAESI Act 2002, is India's closest to the U.S law of Article 9 of the Uniform Commercial Code (UCC). While the latter only governs credit transactions secured with personal (movable) property; the SARFAESI Act applies to credit transactions for which the underlying repayment obligations are either secured with a movable or an immovable asset. ${ }^{38}$ Like the UCC Article 9-609, the SARFAESI Act provides a secured lender with a private enforcement remedy against a debtor's collateral in the event of default. ${ }^{39}$ Two of the main remedies include the power to repossess collateral and also take over management of the debtor's business as means of satisfying indebtedness. ${ }^{40}$ It should be noted that the SARFAESI Act does not apply to retention of title devices: such as conditional sale, hire purchase, and equipment leasing. ${ }^{41}$ On the contrary, the UCC Article 9's unitary system uses a functional test to ascertain whether a credit transaction falls within its purview, and in this case, includes the so-called retention of title devices and the more traditional security devices at common law: i.e., mortgage, charge, pledge, and consensual lien. ${ }^{42}$

Thus, the Indian system, just like its English counterpart, has the four common law security devices (mortgage, charge, pledge, and lien) which exist independent of the retained title devices. These formal distinctions into pure security devices (mortgage, charge, pledge, and lien); and quasi security devices (conditional sale, hire purchase, equipment leasing) with different applicable laws, are as Douglas Baird elaborated, ${ }^{43}$ the biggest source of complexities that fuel the so-called ostensible ownership problem. ${ }^{44}$ Similarly, it generates the possibility that a title contest between a good faith buyer without notice and a retained legal title holder will like-

38 See section 2 of SARFAESI Act on the definition of 'property' which includes the movable and immovable types.

39 Ibid., section 13.

40 Ibid., section 13(4).

41 Ibid., section 31.

42 See Articles 9-109 and 9-203, Uniform Commercial Code.

43 Baird, D. G., 1983, Notice Filing and the Problem of Ostensible Ownership, Journal of Legal Studies, Vol. 12, No. 1, 53-67, p. 54 ("Strictly speaking, pledges of chattels, which were recognized at common law, created ostensible ownership problems as well, because the creditor holding pledged property would appear to own property that in fact belonged to another. Courts and commentators have ignored this problem, perhaps on the ground that those who were creditors were not likely to be borrowers as well. Regardless of whether this rationale was ever sound, it is no longer. Many lending institutions (such as banks) are also borrowers.").

44 Ibid., p. 54: "Strictly speaking, pledges of chattels, which were recognized at common law, created ostensible ownership problems as well, because the creditor holding pledged property would appear to own property that in fact belonged to another. Courts and commentators have ignored this problem, perhaps on the ground that those who were creditors were not likely to be borrowers as well. Regardless 
ly be resolved in favor of the latter, due to the exemption of registration typically granted to retained title transactions. ${ }^{45}$ However, in the U.S, the system does not in any way reward the existence of secret liens and the buyer of a collateral acquires it free of any preexisting encumbrance if the existing security interest in the collateral was not registered in the collateral registry. ${ }^{46}$

Another interesting point to this discourse is the section-13 power of the SARFAESI Act. This power is similar to the type conferred to the holder of a floating charge under the Indian Companies Act 2013, ${ }^{47}$ which entitles the holder to appoint a receiver. ${ }^{48}$ As McCormack explained, receivership is a $20^{\text {th }}$ century creature of English law and arises out of a crystallized floating charge. ${ }^{49}$ In England, (the country of its birth), the floating charge concept has received heavy criticisms as being too creditor-friendly. ${ }^{50}$ Jacob Ziegel offers rich reflection on the device's ability to oust a management from operation, i.e., the appointed receiver: although charged to act for the benefit of all stakeholders, usually acts for the principal benefit of his appointor. ${ }^{51}$ In many cases, as explicated by McCormack, quite a number of appointed receivers typically create sham companies and transfer valuable assets of the distressed company during their short term in office. ${ }^{52}$ In the case of India, the only safeguard against the misuse of floating charge, which is argued to be insufficient, is the provision that addresses 'sick companies' under the Companies Act 2013, which allows a secured creditor with up to $50 \%$ of total assets of the sick

of whether this rationale was ever sound, it is no longer. Many lending institutions (such as banks) are also borrowers."

45 See Lord Devlin, in Chow Yoong Hong v. Choong Fah Rubber Manufactory [1962] AC 209 at 216; see generally Worthington, S., 1996, Proprietary Interests in Commercial Transactions, Oxford, Clarendon Press.

46 Lipson, J. C., 2005, Secrets and Liens: The End of Notice in Commercial Finance Law, Emory Bankruptcy Development Law Journal, Vol. 21, p. 426.

47 Section 84, Companies Act 2013.

48 For a classical discussion on floating charge and receivership, see Illington $v$. Houldsworth [1904] AC 355; Agnew v. Commissioner of Inland Revenue [2001] 2 AC 710; Re Spectrum Plus Ltd [2005] UKHL 41, p. 106.

49 See McCormack, G., 1994, Priority of Charges and Registration, Journal of Business Law, p. 587; McCormack, G., Registration of Company Charges, 2009, $3^{\text {rd }}$ ed., Jordans Publishing Limited, p. 321.

50 See the White Paper Insolvency: A Second Chance (Cmnd 5234, July 2001).

51 See generally, Ziegel, J. S., The Privately Appointed Reciever and the Enforcement of Security Interests: Anomaly or Superior Solution?, in: Ziegel, J. S., (ed.), 1994, Current Developments in International and Comparative Corporate Insolvency Law, Oxford, Clarendon Press.

52 McCormack, G., 1995, Reservation of Title, $2^{\text {nd }}$ ed., London, Sweet \& Maxwell, p. 4. 
company to block the possibility of a floating charge holder from ousting the management from operation. .33

\subsection{THE SECOND DIAGNOSED DEFECT: THE CO-EXISTENCE OF TWO OPPOSING FLOATING SECURITIES}

As stated above, the concept of a floating charge security was first invented by English courts. Under Indian law, the floating charge concept is contained in section 84 of the Companies Act 2013. The security device can only be created by a corporate debtor, and its existence is important to commerce and access to credit, given its monopolistic status as the only way a borrower's stock-in-trade or inventories could be used as collateral to secure payment. ${ }^{54}$ As explained by the UK Privy Council in Re Brumark Investments Ltd, an integral part of a floating charge is its allowance on the borrower to use encumbered assets in the ordinary course of business, including the disposal of such assets without any prior consent from the charge holder. ${ }^{55}$ In other words, the floating charge will continue to hover on present and after-acquired assets until crystallization occurs, which could be the borrower's default in repayment or insolvency. ${ }^{56}$ Crystallization causes the floating charge to settle and attach on the encumbered assets, and by that very fact, it becomes a fixed charge on the category of assets on which it previously hovered.

Imagined from the forgoing perspective, the floating charge was therefore an improvement upon fixed charge because as already stated, it is the only commercially practicable way of securing credit with inventories: fixed charge requires the debtor to notify and first of all obtain consent from the fixed charge holder before disposal of any underlying assets, which is admittedly impracticable with shifting assets, i.e., inventories. Being that a fixed charge creates an in rem security right against a specific asset of the debtor/fixed chargor, if that asset is removed from the debtor's business, the in rem security right of the fixed charge holder against that specific asset would be lost and become automatically converted into an in personam right against the debtor and enforceable only through a

53 Section 253(2) Companies Act 2013, India.

54 Gullifer, L., 2008, The Reforms of the Enterprise Act 2002 and the Floating Charge as a Security Device, Canadian Business Law Journal, Vol. 46, 399, p. 403.

55 Re Brumark Investments Ltd [2001] UKPC 28 is also known as: Agnew v. Commissioner of Inland Revenue [2001] 2 AC 710; Re Yorkshire Woolcombers Association Ltd [1903] 2 Ch., para. 295.

56 See Illingworth v. Houldsworth [1904] AC 355. 
court action. Unlike an in rem right, a right in personam does not entitle the creditor the right to privately repossess and sell collateral: however, a 'fixed charge' confers such right if agreed by the parties. ${ }^{57}$

In India, two floating securities unfortunately coexist. The first is the floating charge contained in section 84 of Companies Act 2013, and the second is the type called 'hypothecation' under section 2 of the SARFAESI Act, defined as "a charge in or upon any movable property, existing or future, created by a borrower in favor of a secured creditor without delivery of possession of the movable property to such creditor, as a security for financial assistance and includes floating charge and crystallization of such charge into fixed charge on movable property." ${ }^{8}$ A combined reading of the wordings used in defining 'security agreement' and 'security interest', shows that a 'hypothecation' as defined by the SARFAESI Act is a fixed cum floating security device, in that, a security interest in favor of a secured creditor is created, and thus attaches on the debtor's assets on existing or future movable assets during the time the security agreement was executed.

Accordingly, the principal difference between the two floating security devices is that while the Companies Act-governed floating charge can postpone attachment of the secured creditor's interest in a category of debtor's assets until crystallization, the hypothecation does not require crystallization to attach: attachment to the assets-collateral occurs in the beginning following execution of the security agreement by parties. Therefore, the danger of their co-existence ${ }^{59}$ refers to the fact that while both types of securities empower their holders to appoint a receiver with power to oust the debtor from management, a perfected hypothecation based security interest would rank higher than a subsequently crystallized floating charge. ${ }^{60}$

Pennington, ${ }^{61}$ offered an account of how the floating charge concept was roundly rejected by U.S courts especially in Benedict v. Ratner: ${ }^{62}$ float-

57 See Agnew v. Commissioner of Inland Revenue [2001] 2 AC 710; Re Brightlife Ltd [1987] Ch 200; Siebe Gorman v. Barclays Bank [1979] 2 Lloyd's Rep. 142.

58 Italics, mine.

59 For an elaborate explanation regarding the consequences of co-existence, see: Iheme, W. C., and Mba, S. U., 2017, Towards Reforming Nigeria's Secured Transactions Law: The Central Bank of Nigeria's Attempt through the Back Door, Journal of African Law, Vol. 61, p. 140.

60 This is because, for the SARFAESI hypothecation, attachment on the debtor's assets occurs from the outset, while in the Companies Act floating charge, attachment on the debtor's assets occurs only upon crystallization. See Millett LJ (as he then was) in Re Coslett (Contractors) Ltd [1998] Ch 495 at 510.

61 Pennington, R. R., 1960, The Genesis of the Floating Charge, The Modern Law Review, Vol. 23, No. 6, p. 630.

62 See Benedict v. Ratner (1925) 268 US 354; Zartman v. First National Bank (1907) 189 NY 267. 
ing charge was thought to be an enabler of fraud due to its main characteristic that allows a debtor to deal with encumbered assets in the ordinary course of business including the possibility to sell them to a third party. In other words, U.S courts worried about the so-called 'ostensible ownership' problem that seems to be a natural consequence of the floating charge, especially in the $20^{\text {th }}$ century when the idea of chattel mortgage and nonpossessory securities (perfected via registration) was new and considered a radical concept, compared to the more entrenched concept of possessory pledge which was already deep seated in the Twyne's Case. ${ }^{63}$

Until the arrival of UCC Article 9 in the mid- $20^{\text {th }}$ century, which ushered in the 'floating lien' concept, ${ }^{64}$ the U.S system lacked a floating security device, and did not provide a precise formula on how to use shifting assets to secure debt. Yet unlike its English counterpart, the Article 9 floating lien is not totally floating per se, and requires no crystallization to be enforceable just like the SARFAESI hypothecation, because attachment occurs from the onset after execution of security agreement: it embodies both the fixed and floating concepts, and could be created by both individuals and corporations unlike the floating charge which can only be created by corporations. ${ }^{65}$

Based on the forgoing, it is submitted that the existence of two floating securities in one legal system, as in India, is a misnomer and potentially dangerous. Perhaps, this explains why neither the United Kingdom nor the United States (the countries of birth of the two floating securities), has both securities in simultaneous operation. The reason for this refers to what has earlier been stated: a floating charge postpones its 'attachment' on the debtor's assets until a crystallizing event occurs, and upon crystallization, the charge queue's behind other preexisting fixed charges and can only be satisfied if the common assets are sufficient for the senior fixed charge holders. Thus, for a creditor, the real value of a floating charge as McCormack rightly explained lies in the control power to oust debtor from operation. ${ }^{66}$

63 [1601] 76 ER 809. See also Goode, R., 1988, Legal Problems of Credit and Security, London, Sweet \& Maxwell, p. 10; Sykes, E., Walker, S., 1993, The Law of Securities, Law Book Company, pp. $734-737$. For a Polish perspective on pledge, see Spanogle, J. A., 2010, Secured Transactions Law in Eastern Europe: the Polish Experience as an Example, Thomas Jefferson Law Review, Vol. 31, p. 291.

64 Article 9-204(1), Uniform Commercial Code.

65 On the applicability of charges over types of assets, see generally: Oditah, F., 2001, Fixed Charges over Book Debts after Brumark, Insolvency Intelligence, Vol. 14, 49; Oditah, F., 2004, Fixed Charges and Recycling of Proceeds of Receivables, Law Quarterly Review, Vol. 120, 533; McCormack, G., 2002, The Nature of Security over Receivables, Company Lawyer, Vol. 23, 84.

66 McCormack, G., 2003, The Floating Charge and the Law Commission Consultation Paper on Registration of Security Interests, Insolvency Lawyer, Vol. 3, pp. 92-100. 
At some point however, the UK started to have a rethink on the use of floating charge, and as explicated by professor Gullifer ${ }^{67}$ floating charge in the United Kingdom since the 2002 Enterprise Act no longer confers creditors the power to oust a debtor from operation, but the right to appoint an administrator. In order to encourage and promote the philosophy of business rescue which was one of the aims of the Cork Committee, ${ }^{68}$ as well as the reformers of the IBC 2016, India needs to borrow leaf from the United Kingdom by amending the powers of a floating charge holder (including the section-13 power of a SARFAESI creditor) to only entitle a holder to commence an insolvency resolution process under the IBC 2016 , instead of the self-help power to take over a business which intrinsically conflicts with the notion of rescue. Similarly, the conflicts between the SARFAESI Act 2002 and Companies Act 2013 due to the co-existence of the differing floating securities and their concomitant powers and effects need to be resolved, with the possibility of reforming the system either through the English or U.S approach.

\title{
3. Unique (But Problematic) Features OF THE INSOLVENCY AND BANKRUPTCY CODE 2016
}

\author{
3.1. THE THIRD DIAGNOSED DEFECT: \\ A STRANGE CATEGORIZATION OF CREDITORS
}

Professor Tajti presented a comprehensive account of security interest legal frameworks of many common and civil law jurisdictions, including those of United States and United Kingdom. ${ }^{69}$ In those jurisdictions, creditors have generally been categorized as either 'secured' and 'unsecured creditors'; the latter category could further have a subset called the 'preferential unsecured' creditors. ${ }^{70}$ A secured creditor is one who has a security interest (in rem) right against specific assets of the debtor; while an

67 Gullifer, L., 2008, The Reforms of the Enterprise Act 2002 And The Floating Charge as A Security Device, Canadian Business Law Journal, Vol. 46, 399, p. 419.

68 Cork, K., 1988, Cork on Cork: Sir Kenneth Cork Takes Stock, London, Macmillan, p. 195.

69 Tajti, T., 2013, Testing The Equivalence of the New Comprehensive Australian Personal Properties Securities Act, Its Segmented European Equivalents and the Draft Common Frame of Reference, Bond Law Review, Vol. 24, Iss. 1, section II; Tajti, T., 2002, Comparative Secured Transactions Law, Budapest, Akadèmiai Kiadó, parts II and III, respectively deal with security interests in Europe and North America.

70 Munerry, J., 2020, The Difference Between Secured and Unsecured Creditors, Begbies Traynor (https://www.begbies-traynorgroup.com/articles/director-advice/the-difference-between-secured-and-unsecured-creditors). 
unsecured creditor is one whose right is in personam (the right to sue the debtor), but not specifically against any of the debtor's identifiable assets. ${ }^{71}$ In both UK and U.S, a debt restructuring process requires the general body of creditors to be divided into classes, ideally, creditors whose debts are similar in nature or relate to a specific collateral. ${ }^{72}$ The creditors being divided into classes have the right to vote democratically, and confirm a debt restructuring proposal if 75 percent of each class vote in favor of a plan. ${ }^{73}$

Under the IBC 2016, creditors are divided into 'financial creditors' and 'operational creditors: ${ }^{74}$ a creditor is in the latter category if their debt falls into the definition of an operational debt, and in the case of a financial creditor, if their debt is a 'financial debt.' ${ }^{75}$ Therefore, default, which is the trigger for commencing a cash-flow insolvency, is functionally different for both categories of creditors under the IBC 2016. In relation to cash flow insolvency, i.e., insolvency on the ground of inability to repay debt, the 2013 Companies Act abolished the twenty-one days' grace period for repayment of debt after demand, ${ }^{76}$ which used to be required from all categories of creditors: only after lapse of the grace period was the creditor statutorily permitted to commence a winding up proceeding against the debtor.

However, under the IBC 2016, statutory demand of debt is excused for financial creditors; in other words, following a corporate debtor's default in repayment, the former could without first making a demand, file a petition with the National Company Law Tribunal (Tribunal) to commence an insolvency resolution process, and a decision could be made ex parte by the Tribunal without any opportunity for the debtor to be heard on the matter. ${ }^{77}$ This approach conflicts with the equality principle and even the fair hearing requirements under Articles 14 and 21 of the Indian Constitution, which have been deeply recognized as cardinal principles of natural justice. The unfairness and discrimination exerted by the IBC 2016 are further accentuated by the fact that operational creditors are still required to first make a formal demand: ${ }^{78}$ only after ten days have lapsed

71 See Lord Hoffmann's explanation of the differences between in rem and in personam rights: In Re BCCI (No. 8) [1998] AC 214.

72 Section 895 English Companies Act 2006; on the meaning of 'creditor' for the purpose of restructuring and voting, see Re Te N Ltd and Others [2006] 3 All ER 697; the Insolvency Act 1986 Part I; Chapter 11 of the U.S Bankruptcy Code.

73 Ibid.

74 Section 5 of the IBC 2016.

75 Ibid.

76 Section 375(4)(d) Companies Act 2013, amended by section 255 (Eleventh Schedule) of the IBC 2016.

77 Compare sections 7 and 8 of the IBC 2016.

78 Ibid. 
and the debtor fails to repay, could they be entitled to approach the Tribunal for a petition to commence an insolvency resolution process against the debtor. ${ }^{79}$ The approach of the IBC 2016 in this regard, also negates the common law rule of detinue, ${ }^{80}$ being followed in the UK and other common law systems, to the effect that in respect of a personal property or debt, a default in repayment does not automatically ripen to a cause of action, neither will it be sufficient to commence an insolvency process until a demand for it has been made, and the debtor refuses to repay after grace period. ${ }^{81}$

In the author's view, there is no reasonable justification or explanation for the strange categorization and preferential treatment accorded to financial creditors other than the possibility of 'regulatory capture' of the lawmakers who placed the interest of the financial industry over those of nonfinancial industries: the latter category also plays a crucial role in the lives and survival of small businesses in the Indian economy. ${ }^{82} \mathrm{~A}$ financial creditor's IBC-power to approach the Tribunal ex parte and possibly secure a petition to commence a resolution process against its debtor, perhaps, through a self-nominated insolvency resolution practitioner, could lead to an abrupt liquidation of a financially healthy company which had inadvertently forgotten to repay a due debt. There could be a myriad of reasons why a company could forget to repay a due debt, which include but not limited to an unavoidable absence of the corporate debtor's accountant. In this sense, the IBC 2016 harbors a dangerous approach that stokes the pro-liquidation concept: this is incongruous with the philosophy behind business rescue and preservation of employments. In this regard, the IBC 2016 should be reformed to require financial creditors to furnish a demand notice, just like their operational counterparts.

\subsection{THE IMPLICATIONS OF IBC'S CATEGORIZATION OF CREDITORS AND THE LIKELY IMPACT ON BUSINESSES}

Building on the forgoing points, it has been established that being christened a 'financial creditor' under the IBC 2016, comes with certain enviable rights over operational creditors. First, apart from being exempt

79 Ibid.

80 For a definition of detinue, see Black's Law Dictionary, $8^{\text {th }}$ ed. 2004, p. 1355.

81 Section 123(1)(a), Insolvency Act 1986.

82 In broad comparison with EU law, it may be said that the special privileged legal regime applicable to financial creditors in India is somewhat based on similar considerations as the European Union's Financial Collateral Arrangements Directive: Directive 2002/47/EC, (https://eur-lex.europa.eu/legal-content/EN/TXT/?uri=celex:32002L0047). 
from the obligations to first make a formal demand after default, ${ }^{83}$ which thus entitles them to spring a deadly surprise at a debtor with the possibility of obtaining an ousting verdict from the Tribunal, they are also entitled to exclusively form the committee of creditors $(\mathrm{CoC}) .{ }^{84}$ Being that the IBC 2016 does not allow a direct launch of liquidation on grounds of inability to pay debt without starting from the insolvency resolution process, the commencement of a resolution process by an operational creditor with less than $10 \%$ of total debt value does not necessarily mean that they will be entitled to make decisions on how to restructure the debtor's repayment obligations or even be repaid in full. ${ }^{85}$

As earlier stated, as the formation of $\mathrm{CoC}$ is an exclusive right of the financial creditors, the fate of the operational creditors is left entirely in the former's hands: the IBC 2016 only requires a CoC to provide for operational creditors, something 'better than' what they would have received in liquidation. ${ }^{86}$ The motive behind this overt partiality of the IBC 2016 should be investigated to ascertain whether the 2016 insolvency reform was a mere regulatory capture of lawmakers by the financial institutions. The result of the biased treatment has unwittingly caused operational creditors to lose hold of the globally recognized approach which ensures that a creditor with an in rem security right is given access to vote and determine how underlying debts on their assets will be determined. ${ }^{87}$

Second, India being a developing economy with more than $80 \%$ of the business entities regarded as medium, small and medium scale enterprises (MSMEs), the importance of operational creditors in its economy's short and long term growth cannot be overemphasized. As hinted above, section 31 of the SARFAESI Act excludes retained title devices from its purview, and based on a common sense interpretation of the IBC's definition of 'debt', ${ }^{8}$ a creditor's right which emanates from a retention of title transaction will only entitle them an 'operational debt' against the debtor. Therefore, with the discrimination of operational creditors under the IBC 2016, and with much preference given to those with financial debts, what this means is that MSMEs requesting the supply of services, and goods (especially equipment and inventories) on a retention of title basis to run

83 Section 7 IBC 2016.

84 Ibid. at Section 21(2).

85 Ibid. at Section 24(3)(c).

86 Ibid. at Section 24(3)(c); Section 30(2)(b).

87 See generally, Clarke, A., 1997, Security Interests as Property: Relocating Security Interests within the Property Framework, in: Harris, J. W., (ed.), Property Problems from Genes to Pension Funds, London, Kluwer.

88 Section 5 IBC 2016. 
their businesses would increasingly be denied by their sellers or suppliers given the abysmal position afforded to them in insolvency.

Third, the position of the IBC 2016 in respect of the categorization of creditors would in the long run discourage supply of goods and services on sale credit. Yet, this is basically how most small businesses especially grocery stores or supermarkets relying on the sale of inventories, function on a daily basis. Unfortunately, the IBC 2016 seemed to have cared little about how the bulk of economic transactions occur in India: thus, it is predicted that as insolvency cases accumulate, enough to clearly show the real effects of the unfair distinction of creditors, i.e., operational creditors realizing better that their interests are not adequately protected in insolvency, it will reach a point when the request to supply goods and services on a sale credit basis would be rarely honored, further diminishing the ease of doing business in India. In fairness, there is no good reason to exclude operational creditors, some of whom have security interest rights in specific debtor's assets, from becoming members of the CoC: it cannot be overemphasized that their interest and voice ought not to be excluded from a decision-making process of debt restructuring that critically affects them.

Fourth, the radical approach of the IBC 2016 in the forgoing has triggered a frantic race among creditors towards being recognized as financial creditors in the context of a debtor's insolvency. Even the IBC itself did not provide a comprehensive definition or a closed list of examples in respect of what constitute a financial debt. An important case that shows the existence of uncertainties regarding the meaning of financial debt is the Indian Supreme Court case in Pioneer Urban Land and Infrastructure Limited v. Union of India (2019), also known as the Home Buyers' Case. ${ }^{89}$ In that case, the home buyers had advanced monies to an estate developing company for the purchase of flats in a property yet to be developed. When the company could not complete the building and was undergoing an insolvency resolution process, the question was whether the home-buyer depositors could be regarded as financial creditors: in the definition of financial debt under the IBC 2016, charging of interest rate is an integral element for being a financial creditor. Since the home-buyer advance payments were not in any way a loan in the literal and traditional sense and no interest was paid on it, it was argued that their financial deposits only constituted operational debts.

In what seemed groundbreaking in the real estate and legal industries, the Supreme Court held that the home-buyers' contracts had a 'borrowing effect' which qualified them to become financial creditors, and thus entitled to be in the $\mathrm{CoC}$. The Court reasoned that the monetary

89 Judgment dated August 9, 2019 in Writ Petition (Civil) No. 43/2019. 
advance for a proprietary right on a property that was yet to come into existence, could functionally be regarded as loans, and in any case, the nonperformance of the contract resulted into failure of the consideration (money) which on the basis of trust law, ought to revert to the depositors, with a default interest rate which by that very fact qualified their debts as financial. ${ }^{90}$

This particular decision has put the Indian parliament to shame, and shows the unacceptable level of ambiguity of the IBC 2016, for which the Supreme Court is now dissociating itself from the hidden motive of parliament in respect of the legislation. In this regard, an Indian court faced with a task of interpreting or evaluating decisions emanating from the Tribunal should be sufficiently bold to raise its head above the parapet in disregard of any literal but absurd interpretation of the IBC 2016 that is not predicated on equity and good justice.

\section{Reimagining the Corporate Rescue Culture in INDia}

\subsection{PURE INFORMAL RESCUE: 'WORKOUT' AND THE 'LONDON APPROACH'}

For more than three decades, the notion that a company is worth more alive than dead has thrived in the United Kingdom and United States, and many countries including India have attempted a shift from being a creditor-friendly system to the debtor-friendly type: the latter encourages restructure of debts towards saving a company in distress. As elucidated by Sanford Mba, talks about debt restructuring usually begin informally based on existing contracts between a debtor and its creditors, and could if unsuccessful, mature to a more formal process like reorganization or liquidation. ${ }^{91}$ So, an informal workout that is contract-based could be regarded as being on the extreme of the continuum, while reorganization (rescue) and liquidation could be seen to occupy the other end of it.

In a workout approach, a corporate debtor and its creditors are only bound by the normal rules of contract, which of course, embody the possibility of breaches as well as remedies: the remedies comprise of damag-

90 On the effects of failure of consideration, see Goodhart, W., Gareth, J., 1980, The Infiltration of Equitable Doctrine into English Commercial Law, Modern Law Review, Vol. 43, 489, p. 508; see generally, Goodhart, W., 1986, Clough Mill Ltd v. Martin - a Comeback for Romalpa? Modern Law Review, Vol. 49, 96.

91 Mba, S., 2019, New Financing for Distressed Businesses in the Context of Business Restructuring Law, Springer, pp. 76-78. 
es, specific performance, and any other inherent powers of court, such as injunctions. Normally, given the heightened need for confidentiality in an informal rescue process, i.e., the need to ensure that sensitive news about the looming financial distress of a company does not leak into the hands of its employees, certain creditors, the general society, the debtor company and its creditors may begin informal talks by executing a non-disclosure agreement, even though, this will not guarantee the debtor any total assurance of the creditors' commitment not to breach the agreement. ${ }^{92}$ The workout process has a more solid root in England, with a nickname: the "London Approach", 93 which characterizes a practice whereby lead banks of the debtor could champion the workout process and get other 'smaller' lenders to agree to a viable solution.

McCormack's explanation exposed the hidden motive that lurks in the use of floating charges: under the 1990 pure creditor-friendly regime in England, whereby a floating charge holder could upon crystallization of his charge, gain control of the debtor's assets, thus enjoying the possibility of misusing assets of other creditors. ${ }^{94}$ Therefore, junior unsecured creditors aware of this possibility were not too difficult to convince about the inherent benefits of a workout process. For example, banks and credit card companies, unlike in India where they are regarded as financial creditors, do not have any specific assets of the debtor and thus run the risk of being repaid pari passu in the context of liquidation. ${ }^{95}$ Hence, apart from the financial institution holding a floating charge against a debtor, all other creditors without a floating charge were easy to convince in joining to sing the hymn that "a company is better kept alive than dead", 96 with the hope of being repaid in full at a future agreed date.

92 Gudgeon, M. R., Joshi, S. A., 2013, The Restructuring and Workout Environment in Europe, in: Larkin, B., (ed.) Restructuring and Workout Strategies for Maximizing Value, $2^{\text {nd }}$ ed. Globe, Law and Business, pp. 7-14.

93 Armour, J., Deakin, S., 2001, Norms in Private Insolvency: The "London Approach" to the Resolution of Financial Distress, Journal of Corporate Law Studies, Vol. 1, part 1, 21-51, p. 22; Flood, J., The Vultures Fly East: The Creation and Globalisation of the Distressed Debt Market, in: Nelken, D., Feest, J., (eds.), 2001, Adapting Legal Cultures, Oxford, Hart Publishing, pp. 257-278.

94 McCormack, G., 1995, Reservation of Title, $2^{\text {nd }}$ ed., London, Sweet \& Maxwell, p. 4.

95 For a comprehensive understanding of pari passu, see: Wood, P., 2003, Passu Clauses-What Do They Mean?, Butterworths Journal of International Banking \& Financial Law, Vol. 18, No. 10; Olivares-Caminal, R., 2009, To Rank Pari Passu or Not to Rank: That Is the Question in Sovereign Bonds after the Latest Episode of the Argentine Saga, Law \& Business Review of the Americas, Vol. 15, No. 4, p. 745; Buchheit, L., Pam, J., 2004, The Pari Passu Clause in Sovereign Debt Instruments, Emory Law Journal, Vol. 53, p. 913.

96 Verdoes, T., Verweij, A., 2018, The (Implicit) Dogmas of Business Rescue Culture, International Insolvency Review, Vol. 27, No. 3, p. 409; Dew, N., Goldfarb, B., Saras- 
India, regardless of its IBC 2016, still has the UK type of pure creditor-friendliness that was modified by the 2002 Enterprise Act. Given that $90 \%$ of India's business entities are small, ${ }^{97}$ and given its population of 1.3 billion people,${ }^{98}$ the need to keep businesses alive as well as preserve jobs, by creating a true debtor-friendly system as is currently in the U.S, has become highly important.

\subsubsection{A Hybrid Solution: The Scheme of Arrangement?}

The Scheme of Arrangement (the Scheme) is a hybrid creature that draws life from private contract on one hand, and from a statutory-like contract backed up by court sanctions, on the other hand. ${ }^{99}$ In other words, the Scheme is a tripartite agreement involving the debtor, its creditors, and the court/supervisor. It is a company law remedy, and being so, it is not regarded as an insolvency process because it could be commenced by a company that is a not yet cash flow insolvent.

Historically, the Scheme's existence was first found in English law, and presently, as observed by professor Payne, it has become an integral part of the company law statutes of many common law jurisdictions, including India ${ }^{100}$ and the continental legal systems. ${ }^{101}$ In India, as Umakanth Varottil also explained, ${ }^{102}$ the essential properties of the Scheme as known under English law, have been retained, even though the Indian Scheme is rarely used to restructure debts compared to the high frequency of use in the United Kingdom. ${ }^{103}$ One possible reason could be that the latter is a bigger economy and has experimented with the Scheme for a much

vathy, S., 2006, Optimal Inertia: When Organizations Should Fail, Advances in Strategic Management, Vol. 23, p. 73.

97 See SME Sector in India: Statistics, Trends and Reports. (https://evoma.com/business-centre/sme-sector-in-india-statistics-trends-reports/\#: :text=Number\%20of\%20 SMEs\%20in\%20India,\%2C\%2040\%25\%20of\%20India’s\%20workforce. 12. 9. 2020).

98 The World Bank Data, 2019, (https://data.worldbank.org/indicator/SP.POP. TOTL?locations=IN, 12. 9. 2020).

99 For a penetrating discussion regarding Schemes of Arrangement in India, see Varottil, U., 2017, The Scheme of Arrangement as a Debt Restructuring Tool in India: Problems and Prospects, European Company and Financial Law Review, Vol. 15, Iss. 3, pp. 585-615.

100 See Varottil, U., 2016, The Evolution of Corporate Law in Post-Colonial India: From Transplant to Autochthony, AmericanUniversity International Law Review, Vol. 31, p. 253.

101 Payne, J., 2014, Schemes of Arrangement: Theory, Structure and Operation, Cambridge, Cambridge University Press, p. xiii.

102 Varottil, U., 2017, pp. 586-587.

103 Ibid., p. 588. See Pilkington, C., 2013, Schemes of Arrangement in Corporate Restructuring, London, Sweet \& Maxwell, pp. 1-3; Gallagher, A., 2010, The Growth of 
longer period compared to India, which until 1991, was a closed economy that was largely state-run. Undeniably, in a state-run economy where the factors of production belong to the state, it is difficult to have a market-tested body of jurisprudence that addresses a significant number of the challenges emanating from the experiences of debt restructuring or liquidation: this cannot be achieved without a sufficient degree of market experience, regardless of the existence of the restructuring mechanisms in the blackletter law.

Similarly, the efficiency test of a system's rule of law is measured by the independence and effectiveness of its judiciary. In the case of India's Scheme, it was observed that its efficacy and attraction to creditors were whittled by the length of time it took on average to conclude the Scheme process. ${ }^{104}$ Another observed reason was the introduction of other types of debt restructuring mechanisms, for instance, the corporate debt restructuring (CDR), which was the brain child of the India's Reserve Bank. In many respects, as explained by Sengupta et al., the CDR was modelled after the London Approach, which gave banks and other financial institutions the mandate to drive the process and achieve viable results, out of court. ${ }^{105}$

The second type of debt restructuring mechanism introduced into the Indian system even after the existence of the Scheme, was the Sick Industrial Companies (Special Provisions) Act 1985 (SICA). SICA (through its management board) was introduced to swiftly manage the rescue process of many of the distressed companies. ${ }^{106}$ However, one major distinction between the SICA mechanism and the Scheme's, is that while the latter's process does not confer a moratorium to a debtor-company until court has confirmed a voted plan, a SICA process confers a moratorium to the debtor, which created gaps for exploitation by some directors of debtor-companies who commenced the process merely as delay tactics, encouraged also by the fact that they were not ousted from management or supervised by court. ${ }^{107}$

Schemes of Arrangement as the Tool of Choice in Complex Restructurings, American Bankruptcy Institute Journal, Vol. 29, October issue, p. 36.

104 Varottil, U., 2017, p. 603. See Ministry of Finance, Government of India, Interim Report of the Bankruptcy Law Reform Committee, 2015, p. 77, (http://finmin.nic.in/reports/Interim_Report_BLRC.pdf, 12.9. 2020).

105 Sengupta, R., Sharma, A., and Thomas, S., 2016, Evolution of the Insolvency Framework For Non-Financial Firms in India, p. 11 (http://www.igidr.ac.in/pdf/publication/WP-2016-018.pdf, 10. 9. 2020).

106 Varottil, U., 2017, p. 588.

107 Zwieten, K., 2015, Corporate Rescue in India: The Influence of the Courts, Journal of Corporate Law Studies, Vol. 15, Issue 1, p. 3; Gupta, S.K., 2014, Corporate Rescue 
The forgoing was further reinforced by the Indian Supreme Court in Tata Motors Ltd. v. Pharmaceutical Products of India Ltd, ${ }^{108}$ which held SICA to be a special statute and thus trumps over the Scheme which emanates from the Companies Act (a general statute), on the principle of law that where there is a conflict between a special statute and general statute over an issue, the latter is made subservient. ${ }^{109}$ However, it is important to note that SICA was repealed owing to the enactment of the IBC in 2016, thus leaving India with the Companies Act-Schemes ${ }^{110}$ and the insolvency resolution process as the system's debt restructuring mechanisms. However, with a purposive mindset, the question is: how effective are these two mechanisms?

\subsubsection{India’s Corporate Rescue Mechanisms: How Sufficient Are They?}

For cash flow insolvency, the IBC 2016 provides a single entry point: a rescue is first attempted, ${ }^{111}$ and if unsuccessful, then liquidation. In other words, unlike in the U.S or UK, there is no initial possibility to commence a liquidation process, without first attempting to rescue the distressed company. On a prima facie assessment, the Indian approach could therefore qualify as the champion of 'business rescue': a notion that started to dominate the scene in the UK following Cork's recommendations and the 1990 economic recession. However, when functionally examined, some serious contradictions are visible in the Indian rescue approach. First, as earlier hinted, the 2013 Companies Act abolished SICA which is a functional equivalent of the CVA that retained management in office and bequeathed it with a moratorium: the 2013 Companies Act only retains the Scheme which is a debtor-in-possession, but without a statutory moratorium that disables creditors' rights to sue or repossess collateral while a Scheme is in process. ${ }^{12}$

An interesting fact that should assist in shaping the way IBC 2016 is assessed, is that bulk of the existing companies in India are fami-

in India: Trends and Prospects, International Company and Commercial Law Review, Vol. 11, Issue. 3, 241, p. 243.

108 (2008) 114 Comp. Cas. 178 (SC); Madura Coats Limited v. Modi Rubber Ltd (2016) Comp. Cas. 261 (SC).

109 Ibid., (Tata Motors Ltd) at paras. 20, 21; (Madura Coats Ltd), ibid. at para. 27; Varottil, U., 2017, p 602.

110 Section 230 Companies Act 2013.

111 See the Eleventh Schedule of IBC 2016 which amends section 271 Companies Act 2013 by removing "unable to pay its debt" as a ground for winding up (liquidation) of a company.

112 Section 230 Companies Act 2013, India. 
ly-owned, ${ }^{113}$ such that the promoters are often the directors, who in large part, will have enough interest to ensure that the distressed company is jumpstarted. Barring a few exceptions whereby promoters float a company mainly to defraud the public, in which case, the corporate law rules on piercing the veil have been effective to pinpoint and punish wrongdoers; ${ }^{114}$ other times, it becomes very destabilizing and unproductive to oust debtors of family-owned businesses from management due to default in repayment of debts.

Thus, India being a country with many promoter-run small companies, coupled with the highly trumpeted rescue culture of the IBC 2016, one would have expected a model that is similar to CVA for small companies in the UK, where the management of a distressed company is retained, given the benefit of moratorium, and a supervisor to work with the corporate debtor and creditors toward ensuring a full implementation of the proposal sanctioned by court. Instead, under the IBC 2016, depending on the nature of debt, the management could be ousted from their seat even without the concerned debt being first demanded. ${ }^{115}$ As earlier stated, this is made possible due to the strange division of creditors into financial and operational types, and for the former, they can automatically approach the Tribunal with a petition to commence an insolvency resolution process, after a default of repayment has occurred.

Yet, based on settled common law, a cause of action premised on debt is not automatically ripe until a demand for repayment has been made. Indisputably, this is the reason the Insolvency Act 1986 and many other common law jurisdictions provide that after a default occurs, the creditor must first make a demand for repayment, and only after the lapse of twenty-one days, ${ }^{116}$ will the creditor's cause of action to bring a winding up petition be deemed ripe. Hence, for the financial creditors, being largely the banks, India's IBC 2016 waives this requirement, therefore creating a huge element of surprise that can succeed in ousting management without any reminder opportunity to pay or even a fair hearing at the Tribunal.

This high privileged access to the Tribunal is, however, not available to the lesser category of creditors: the operational creditors, whose debts are not financial due to lack of the 'interest rate charge' component.

113 SME Sector in India: Statistics, Trends and Reports (https://evoma.com/businesscentre/sme-sector-in-india-statistics-trends-reports/\#: :text=Number\%20of\%20 SMEs\%20in\%20India,\%2C\%2040\%25\%20of\%20India's\%20workforce., 10. 9. 2020).

114 Salomon v. A. Salomon \& Co. Ltd [1897] AC 22. See generally Keay, A., 2007, Company Directors' Responsibilities to Creditors, London, Routledge-Cavendish.

115 Under the IBC 2016, section 7 creditor's financial debt can oust management from operation without first making a demand.

116 Section 123(2) Insolvency Act 1986. 
Under Indian law, much also like other legal systems, due to financial regulations, only banks, financial institutions and registered money lenders are statutorily allowed to lend money and charge interest on the loan. ${ }^{117}$ Thus, any other form of credit that is not in a loan form and not given by a bank, financial institution or a registered money lender cannot therefore qualify as a financial debt. In this category, all creditors whose debts emanated from retention of title transactions as indicated under section 31 of SARFAESI Act, bond buyers, and other related debt instruments, fall into the designation of operational debtors.

It should be reemphasized that another critical implication of being an operational debtor is that the same element of surprise which is a powerful tool financial creditors brandish against their debtors, is denied and thus a holder of an operational debt must first make a written demand after the corporate debtor's default, and only after the lapse of ten days, will their cause of action mature to entitle them to bring a petition of an insolvency resolution process against the debtor. More so, the stringent conditions under sections 8 and 9 of the IBC 2016, being required of operational creditors to fulfil as an integral part of their application are waived for the financial creditors. Below are the wordings of sections 7 and 8 , which harbor the first part of the discrimination between both categories of creditors.

Section 7 of the IBC reads in part:

"A financial creditor either by itself or jointly with other financial creditors may file an application for initiating corporate insolvency resolution process against a corporate debtor before the Adjudicating Authority when a default has occurred." ${ }^{118}$ (emphasis mine).

Section 8 of the IBC reads in part:

"An operational creditor may, on the occurrence of a default, deliver a demand notice of unpaid operational debtor copy of an invoice demanding payment of the amount involved in the default to the corporate debtor in such form and manner as may be prescribed." ${ }^{119}$ (emphasis mine).

As previously stated, one of the deeply entrenched principles of natural justice which requires a body acting judicial or quasi-judicial to hear from both sides in a dispute before reaching a verdict, or to avail a party the opportunity to know the accusations against them and a corresponding opportunity to respond, is waived against the debtor when a financial

117 Section 5, Money Lenders and Accredited Loan Providers Act, 2007, India.

118 Section 7 of the IBC 2016.

119 Ibid. at section 8 . 
creditor's debt is involved. In the author's opinion, there is no reasonable justification under the IBC 2016 for equating 'default' with the inability to repay debt when a financial creditor is involved, but the same being denied of an operational creditor. As part of the reality of corporate management, especially for less sophisticated small companies, it is possible that default occurred simply because the personnel in charge of accounting forgot to make the necessary payments due to internal disruptions, like being on maternity or annual leave, a sudden resignation of an employee, health emergency, or similar egregious circumstances that happen from time to time in the life and operation of a company.

Of course, in such hard times, default can be easily remedied if a reminder is put up to the corporate debtor. If in the forgoing situation, say, the debtor company is reminded of its due debt, and it promptly pays, then the need for the financial creditor to launch petitions at the Tribunal toward commencing an insolvency resolution process would be obviated, and the associated costs of filing as well as the cost incurred by the Tribunal, which by the way are borne by taxpayers, will all be saved. In addition, this will reduce the amount of needless insolvency resolution cases in the Tribunal's dockets, which are currently clogging its wheels and making it unable to meet up with statutory deadlines. ${ }^{120}$

Looking at the forgoing, it can therefore be said that the IBC 2016 is not true to its self-acclaimed commitment to corporate/business rescue. It is not enough to mandate all insolvency process to first pass through the 'eye of the needle' before going into liquidation: what should be sufficient is an equal treatment of both categories of creditors in respect of commencing resolution processes: that way, financial creditors will cease to run to the Tribunal at the slightest default to commence an insolvency resolution process that could destabilize the life of the company through removal of its existing management.

In light of the forgoing, it is a no-brainer that the Indian approach is susceptible to avoidable abuses because financial creditors wishing to get more money than they are owed might seek to take over management and dictate how the company is run through an implanted insolvency resolution professional. Also, an enemy-competitor to a business could acquire financial debts (e.g., the credit card debts) of its 'enemy' through a debt as-

120 Dutt, I., 2019, IBC Resolutions Exceed New Time Limit of 330 Days Prescribed by Government, Business Standard, (https://www.business-standard.com/article/ companies/ibc-resolutions-exceed-new-time-limit-of-330-days-prescribed-bygovt-119102800661_1.html, 12. 8. 2020): "As on September 30, 2019, 535 of the 1,497 ongoing CIRPs had exceeded the 270-day timeline; 324 had exceeded 180 days but were within 270-day timeframe. The total number of cases admitted were 2,542." 
signment contract from a creditor-financial institution, and upon default, commence a resolution process with the ultimate intention to liquidate the competitor who has inadvertently forgotten to repay the debt when it fell due. If one is in doubt whether the favoritism given to the financial creditors is working against the insolvency regime, the statistics on successful corporate rescue in India should be studied; ${ }^{121}$ it shows a very poor rate of success, which means that a significant number of resolution processes eventually ended up in liquidation. Ironically, the IBC 2016 has thus provided incentives to kill companies even though under the preamble, it claims the exact opposite as its core mission.

\subsubsection{A Sober Reflection on the Corporate Rescuers: The Insolvency Resolution Professionals in India}

In large part, the IBC 2016 is a mirror-image of the English Insolvency Act 1986, especially as it relates to corporate rescue. ${ }^{122}$ Both statutes allow the ousting of an insolvent company's management from operation. The central rationale for this common (Indian/English) approach is that in many occasions, the financial distress of a company is attributable to the mismanagement and corruption of its management board: thus retaining same hands that have caused the company to suffer financial difficulties is thought to be prima facie inconsistent with the notion of good faith rescue. ${ }^{123}$ In that case, the Indian/English approach presumes that corporate failure is caused mainly by internal factors, ranging from corruption to incompetence of the management. On this basis, a third party, i.e., someone with objective values and bespoke expertise (an insolvency practitioner) is expected to resuscitate the company, investigate causes of failure and work closely with courts to punish members of the management found wanting of fraud through misfeasance suits. ${ }^{124}$

In the U.S, the perspective is diametrically opposite, in that the system persuades itself to view corporate financial failure as arising mainly

121 Vivek, K., 2020, A Few Hits \& Some Misses, That's The IBC Track Record, Mint, (https://www.livemint.com/news/india/a-few-hits-some-misses-that-s-the-ibc-trackrecord-11582474699506.html, 10. 8. 2020).

122 Gupta, S. K., 2014, p. 243.

123 See generally, See Kraakman, R. H., 1984, Corporate Liability Strategies and the Cost of Legal Controls, Yale Law Journal, Vol. 93, p. 857; Finch, V., 1994, Personal Accountability and Corporate Control: The Role of Directors' and Officers' Liability Insurance, Modern Law Review, Vol. 57, pp. 881-887.

124 See: The Report of the Review Committee on Insolvency Law and Practice (Cmnd 8558,1982 ) (detecting the causes of failure and punishing directors where necessary was one of the aims of the Cork's Committee). Also see Finch, V., 1997, The Measures of Insolvency Law, Oxford Journal of Legal Studies, Vol. 17, No. 2, p. 227. 
from external factors that are not within the exclusive control of the management. Unlike the Indian/English systems, the U.S system accords a higher premium to the existing expertise of management as the best tool in the rescue process. As professors Elizabeth Warren and Jay Westbrook explained, the DIP model retains the debtor, i.e., the owner or manager of business in possession and brings in an external figure, a U.S Bankruptcy Trustee, a public servant appointed by court and required to work closely with the bankruptcy court in addressing the diagnosed issues throughout the reorganization process. ${ }^{125}$ As earlier hinted, the U.S chapter 11 reorganization is the functional equivalent of the abolished CVA under the 1956 Companies Act of India. The UK does have the CVA model with moratorium for only small companies. ${ }^{126}$ This perhaps, was the source of misunderstanding that caused India to abolish its CVA, and instead took over the Insolvency Resolution Process, the functional equivalent of the English Administration.

The English Administration is nearly 40 years old, and has already garnered enough experiments and experience that should have been sufficient to caution India in 2016 regarding its level of effectiveness. In the UK, Administration has been heavily criticized to be costly and serving as a mere introduction to liquidation. In many cases, English judges were disheartened by the huge cost of Administrators' fees, running into several millions of pounds, incurred against companies that were already impoverished and dying: ${ }^{127}$ indeed, Administrators in the UK have become typically renowned for crushing out dying companies with their heavyweight professional fees. Yet, based on their statutory qualifications and experiences, nothing sufficiently shows that they have the practical knowledge to effectively rescue companies as to justify these high fees.

For instance, in India, also similar to the UK, the educational qualifications and experience requirements for insolvency resolution professionals are documented under section 5 of the Regulations, which is reproduced below:

"Subject to the other provisions of these regulations, an individual shall be eligible for registration, if he - (a) has passed the Limited Insolvency Examination within twelve months before the date of his application for enrolment with the insolvency professional agency; (b) has completed a pre-registration educational course, as may be required by

125 Warren, E., Westbrook, J. L., 2009, The Success of Chapter 11: A Challenge to the Critics, Michigan Law Review, Vol. 107, Issue 4, 603, pp. 604-610.

126 Sch. B1, Insolvency Act 1986.

127 Mirror Group Newspapers plc v. Maxwell [1998] BCC 324, where administrators' fees cost over 35 million pounds. 
the Board, from an insolvency professional agency after his enrolment as a professional member; and (c) has-

(i) successfully completed the National Insolvency Programme, as may be approved by the Board;

(ii) successfully completed the Graduate Insolvency Programme, as may approved by the Board;

(iii) fifteen years' of experience in management, after receiving a Bachelor's degree from a university established or recognized by law; or

(iv) ten years' of experience as -

(a) chartered accountant registered as a member of the Institute of Chartered Accountants of India,

(b) company secretary registered as a member of the Institute of Company Secretaries of India,

(c) cost accountant registered as a member of the Institute of Cost Accountants of India, or

(d) advocate enrolled with the Bar Council." 128

An objective assessment of the forgoing qualifications and experience requirements shows that lawyers, accountants and company secretaries are the people statutorily allowed to become insolvency resolution professionals. This is problematic and poses a serious threat to successful rescue of businesses due to the rescuers' lack of hands-on experiences for most of the businesses they are being asked to rescue. For example, an Indian lawyer with 15 years of law firm experience as required by section 5 of the Regulations, would hardly be able to competently manage, let alone rescue an Information Technology company, chains of supermarkets, factories, and the different types of businesses and companies that exist and operate in India. Similarly, the idea of 'corporate rescue' imagines the intervention of an expert who is not expected to learn the rudiments of operation on the job, or hope to gain specific industry knowledge and cultural practices of the distressed company through trial and error after resumption into office. The ensuing incompetence and lack of awareness of the company's business culture could attract disloyalty from the debtor-company's employees whose expertise and cooperation are very much needed during the period in order to jumpstart the company: ${ }^{129}$ yet the exact opposite of this kind of situation is what distressed companies under the U.S DIP model, enjoy.

128 Section 5 of the Insolvency and Bankruptcy Board of India (Insolvency Professionals) Regulations, 2016.

129 The IBC 2016 imagines the possibility of this situation, and seeks to solve it by demanding for respect and cooperation of the insolvent debtor's employees under section 19 thereof. 
In truth, Administration and its rescue approach have not worked so well even for the UK, the country of its birth, ${ }^{130}$ even though it could justifiably be asserted that in the UK, appointed directors of many of the big companies with dispersed shareholders might afford to invest little emotional interest or become corrupt to the extent that removing them in order to salvage the company for the benefit of creditors remains the only compelling option. ${ }^{131}$ However, in India, most of the businesses or companies are family-owned, and corruption, greed, bad faith, and similar vices, are unlikely to be the true causes of financial distress of a debtor company. Thus, ousting the managers and replacing them with insolvency professionals with no practical, hands-on experience in running that type of business, let alone possess the emotional interest to preserve the family's source of income is tantamount to a death knell for the company.

Another problem here is that under the IBC 2016, an insolvency resolution professional has 180 days to resuscitate the distressed company, ${ }^{132}$ with the possibility of an additional 90 days, if granted by the Tribunal. ${ }^{133}$ It is submitted that a resolution professional with little or no emotional investment in a distressed family-owned business will not have enough incentive to take tedious, swift, and genuine steps in rescuing the company and handing it back to the owners, when there is the guaranteed possibility to earn high fees for 9 months' period, if he intentionally delays matters. However, if the U.S DIP model (equivalent of the erstwhile CVA under the Indian 1956 Companies Act) were to apply in India, with a supervisor assisting to ensure an objective implementation of a court cum creditors' confirmed plan, there would be little or no incentive to prolong a rescue process, and the underlying costs would be minimal, just like in the U.S system where the cost of a chapter 11 reorganization could be as low as \$US $1700,{ }^{134}$ compared to the UK where an administrator's professional

130 Milman, D., 2002, The Administration Order Procedure, Company Law Newsletter, Vol. 17, 1 at 3; Verrill, L., 2004, The R3 Regulation Survey, Recovery, Autumn issue, 27, (stating that "many assets which on the face of it appeared to be the personal property of Mr. Maxwell were either worthless or, because of the immensely complex financial labyrinth which he had constructed, could not ultimately be recovered as personal property." Also see: A Review of the Corporate Insolvency Framework: A Consultation on Options for Reform, 2016, The Insolvency Service, p. 4, (https:// assets.publishing.service.gov.uk/government/uploads/system/uploads/attachment data/file/525523/A_Review_of_the_Corporate_Insolvency_Framework.pdf).

131 See generally, Zwieten, K., 2018, Director Liability in Insolvency and Its Vicinity, Oxford Journal of Legal Studies, Vol. 38, No. 2, p. 382.

132 Section 12(1) IBC 2016.

133 Ibid., section 12(3).

134 US Courts, Chapter 11 - Bankruptcy Basics, (https://www.uscourts.gov/servicesforms/bankruptcy/bankruptcy-basics/chapter-11-bankruptcy-basics, 12. 6. 2020). 
fees alone could cost as high as 35 million pounds, ${ }^{135}$ or up to 5 crore rupees $\left(680,000\right.$ USD) in India. ${ }^{136}$

\section{Conclusion: Where Should India Go From HERE?}

So far, the author has tried to answer the questions posed by this paper. The forgoing analysis reveals some defects in the credit regime of India which emanate from its compartmentalized nature, concomitantly posing difficulties for individuals and small businesses desirous of entering into credit transactions. The paper makes a number of recommendations which can assist in solving the challenge: first, the various security devices scattered into different pieces of legislation and laws, e.g., the SARFESI Act, Companies Act, Hire Purchase Act, Indian Contract Act, law on conditional sale and equipment leasing, applicable common law rules, etc., should all be subsumed into a unitary-functional approach as in the UCC Article 9: 137 the U.S law that applies to secured credit transactions, such that regardless of the label parties christen their transaction, a specific legislation (Article 9) will apply if the function performed by their agreement is to secure a repayment obligation with the debtor's personal property. ${ }^{138}$ If a unitary-functional approach is adopted, it will enhance predictability, reduce the complexities and cost of accessing credit, and impact positively on the ease of doing business in India.

Second the paper recommends the resurrection of the Company Voluntary Arrangement, which used to be part of Indian law under the repealed 1956 Companies Act. Given the unique conditions of India as argued in the paper, the CVA which is the functional equivalent of the U.S chapter 11 DIP reorganization, is more befitting for India because of the comparably lower costs of reorganization, and the fact that most Indian companies are small and family-owned, and cannot generally afford the huge cost of administration/insolvency resolution process.

Third, stemming from the second recommendation, being that the current insolvency resolution process is a prototype of the English Administration, it provides for professionals who are not truly professionals

135 Mirror Group Newspapers plc v. Maxwell [1998] BCC 324, where administrators' fees cost over 35 million pounds.

136 Das, S., 2018, IBBI Looks to Rationalize Fees Structure, The Economic Times, (https:// economictimes.indiatimes.com/markets/stocks/news/ibbi-looks-to-rationalise-feesstructure/articleshow/63584369.cms?from $=\mathrm{mdr}, 10.7$. 2020).

137 See Tajti, T., 2014, pp. 150-157.

138 UCC Article 9-109 (1) (a); Gikay, A., 2017, p. 176. 
in the real sense, or whose expertise is hardly relevant in the rescue of certain types of businesses. For instance, the two main types of professions provided for in the Insolvency Resolution Professionals Regulations: that is, law and accounting are service oriented professions and the experience garnered from a law or accounting firm is for instance, hardly useful in rescuing financially distressed Information Technology, supermarkets, grocery stores, construction companies, and other kinds of businesses involved in product manufacturing with complicated business models. There is no closed list of the types of businesses that can spring up from time to time: therefore, limiting rescue professionals to come from these two professions is a serious mistake, and looks like a placement of narrow interest of lawyers and accountants over the economic interests of individuals and businesses in India. Again, as earlier hinted, this raises questions about the regulatory capture of the IBC 2016 and the appertaining IRP Regulations. The CVA, which mirrors the U.S chapter 11 DIP model should therefore be incorporated back into the Indian insolvency system.

Fourth, and lastly, the categorization of creditors into financial and operational creditors, with undue preferential treatments for the former, is inimical to the overall effectiveness and confidence in the credit and insolvency systems. Bulk of the creditors usually fall into the category of 'operational', and according to the IBC 2016, among other deprivations, they do not qualify to feature into committees of creditors and vote or confirm a rescue plan that affects their in rem security interests in assets-collateral, unlike in the UK and U.S where all creditors vote in their classes to confirm a rescue or reorganization plan.

The privilege to commence a resolution process against a company once a debt is due without first making a formal demand as required of operational creditors, shows that the IBC 2016 is not objective and faithful to the corporate rescue philosophy: there is an urgent need to reform it with awareness of the issues treated above. In any event, the forgoing issues form compelling reasons for the Indian parliament to rethink and reform the IBC 2016 based on the defects diagnosed in this paper in order to rescue it from substantially becoming a harvest of dead leaves.

\section{BIBLIOGRAPHY}

1. Ali, P., 2002, The Law of Secured Finance, Oxford, Oxford University Press.

2. Armour, J., Deakin, S., 2001, Norms in Private Insolvency: The "London Approach" to the Resolution of Financial Distress, Journal of Corporate Law Studies, Vol. 1, part 1.

3. Baird, D. G., 1983, Notice Filing and the Problem of Ostensible Ownership, Journal of Legal Studies, Vol. 12, No. 1. 
4. Black's Law Dictionary, $8^{\text {th }}$ ed. 2004.

5. Buchheit, L., Pam, J., 2004, The Pari Passu Clause in Sovereign Debt Instruments, Emory Law Journal, Vol. 53.

6. Burkart, M., Ellingsen, T., 2004, In-kind Finance: A Theory of Trade Credit, The American Economic Review, Vol. 94.

7. Chiu-Iris, H-Y., 2006, The Legal Fabrication of Security Interests in the United Kingdom, North Carolina Journal of International Law and Commercial Regulation, Vol. 31, No. 3.

8. Clarke, A., Security Interests as Property: Relocating Security Interests within the Property Framework, in: Harris, J. W., (ed.), 1997, Property Problems from Genes to Pension Funds, London, Kluwer.

9. Cork, K., 1988, Cork on Cork: Sir Kenneth Cork Takes Stock, London, Macmillan.

10. Danielson, M. G., Scott, J. A., 2004, Bank Loan Availability and Trade Credit Demand, The Financial Review, Vol. 39.

11. Finch, V., 1994, Personal Accountability and Corporate Control: The Role of Directors' and Officers' Liability Insurance, Modern Law Review, Vol. 57.

12. Finch, V., 1997, The Measures of Insolvency Law, Oxford Journal of Legal Studies, Vol. 17, No. 2.

13. Finch, V., 2009, Corporate Insolvency Law - Perspectives and Principles, Cambridge, Cambridge University Press.

14. Flood, J., The Vultures Fly East: The Creation and Globalisation of the Distressed Debt Market, in: Nelken, D., Feest, J., (eds.), 2001, Adapting Legal Cultures, Oxford, Hart Publishing.

15. Gallagher, A., 2010, The Growth of Schemes of Arrangement as the Tool of Choice in Complex Restructurings, American Bankruptcy Institute Journal, Vol. 29, October issue.

16. Gikay, A., 2017, Rethinking Ethiopian Secured Transactions Law through Comparative Perspective: Lessons from the Uniform Commercial Code of the US, Mizan Law Review, Vol. 11, No. 1.

17. Gilmore, G., 1965, Security Interests in Personal Property, Boston, Little, Brown, Vol. 1.

18. Goode, R., 1988, Legal Problems of Credit and Security, London, Sweet \& Maxwell.

19. Goodhart, W., 1986, Clough Mill Ltd v. Martin - a Comeback for Romalpa? Modern Law Review, Vol. 49.

20. Goodhart, W., Gareth, J., 1980, The Infiltration of Equitable Doctrine into English Commercial Law, Modern Law Review, Vol. 43.

21. Gudgeon, M. R., Joshi, S. A., The Restructuring and Workout Environment in Europe, in: Larkin, B., (ed.) 2013, Restructuring and Workout Strategies for Maximizing Value, $2^{\text {nd }}$ ed. Globe, Law and Business.

22. Gullifer, L., 2008, The Reforms of the Enterprise Act 2002 and the Floating Charge as a Security Device, Canadian Business Law Journal, Vol. 46.

23. Gupta, S. K., 2014, Corporate Rescue in India: Trends and Prospects, International Company and Commercial Law Review, Vol. 11, Issue 3. 
24. Harris, S. L., Mooney Jr. C. W., 1993, The Article 9 Study Committee Report: Strong Signals and Hard Choices, Idaho Law Review, Vol. 29.

25. Iheme, W. C., 2016, Towards Reforming the Legal Framework for Secured Transactions in Nigeria, Springer.

26. Iheme, W. C., Mba, S. U., 2017, Towards Reforming Nigeria’s Secured Transactions Law: The Central Bank of Nigeria's Attempt through the Back Door, Journal of African Law, Vol. 61.

27. Keay, A., 2007, Company Directors' Responsibilities to Creditors, London, Routledge-Cavendish.

28. Kraakman, R. H., 1984, Corporate Liability Strategies and the Cost of Legal Controls, Yale Law Journal, Vol. 93.

29. Li, K., Wang, W., 2016, Debtor-in-Possession Financing, Loan To-Loan, and Loan To Own, Journal of Corporate Finance, Vol. 39, Issue C. Part I and Schedule A1 of theSection 32, Registration Act, 1908.

30. Lipson, J. C., 2005, Secrets and Liens: The End of Notice in Commercial Finance Law, Emory Bankruptcy Development Law Journal, Vol. 21.

31. LoPucki, L. M., 1997, The Systems Approach to Law, Cornell Law Review, Vol. 82.

32. LoPucki, L. M., Abraham, A. I., Delahaye, B. P., 2013, Optimizing English and American Security Interests, Notre Dame Law Review, Vol. 88.

33. Macleod, H., 1876, Principles of Economical Philosophy, Longmans, Green, Reader \& Dyer.

34. Mba, S., 2019, New Financing for Distressed Businesses in the Context of Business Restructuring Law, Springer.

35. McCormack, G., 1994, Priority of Charges and Registration, Journal of Business Law.

36. McCormack, G., 1995, Reservation of Title, $2^{\text {nd }}$ ed., London, Sweet \& Maxwell.

37. McCormack, G., 2002, The Nature of Security over Receivables, Company Lawyer, Vol. 23.

38. McCormack, G., 2003, The Floating Charge and the Law Commission Consultation Paper on Registration of Security Interests, Insolvency Lawyer, Vol. 3.

39. McCormack, G., 2011, American Private Law Writ Large? The UNCITAL Secured Transactions Guide, The International and Comparative Law Quarterly, Vol. 60, No. 3 .

40. McCormack, G., 2009, Registration of Company Charges, $3^{\text {rd }}$ ed., Jordans Publishing Limited.

41. Milman, D., 2002, The Administration Order Procedure, Company Law Newsletter, Vol. 17.

42. Mulligan, M., Tribe, J., 2003, The Remuneration of Office Holders in Corporate Insolvency - Liquidators, Administrators and Administrative Receivers: Part 1, Insolvency Lawyer, Vol. 3.

43. Oditah, F., 2001, Fixed Charges over Book Debts after Brumark, Insolvency Intelligence, Vol. 14.

44. Oditah, F., 2004, Fixed Charges and Recycling of Proceeds of Receivables, Law Quarterly Review, Vol. 120. 
45. Olivares-Caminal, R., 2009, To Rank Pari Passu or Not to Rank: That Is the Question in Sovereign Bonds after the Latest Episode of the Argentine Saga, Law \& Business Review of the Americas, Vol. 15, No. 4.

46. Payne, J., 2014, Debt Restructuring in English Law: Lessons from the US and the Need for Reform, University of Oxford legal Research Paper Series.

47. Payne, J., 2014, Schemes of Arrangement: Theory, Structure and Operation, Cambridge, Cambridge University Press.

48. Pennington, R. R., 1960, The Genesis of the Floating Charge, The Modern Law Review, Vol. 23, No. 6.

49. Pierre, B., 1997, Classification of Property and Conceptions of Ownership in Civil and Common Law, Revue Générale de Droit, Vol. 28, No. 2.

50. Pilkington, C., 2013, Schemes of Arrangement in Corporate Restructuring, London, Sweet \& Maxwell.

51. Spanogle, J. A., 2010, Secured Transactions Law in Eastern Europe: the Polish Experience as an Example, Thomas Jefferson Law Review, Vol. 31.

52. Sykes, E., Walker, S., 1993, The Law of Securities, Law Book Company.

53. Tajti, T., 2002, Comparative Secured Transactions Law, Budapest, Akadèmiai Kiadó.

54. Tajti, T., 2013, Testing The Equivalence of the New Comprehensive Australian Personal Properties Securities Act, Its Segmented European Equivalents and the Draft Common Frame of Reference, Bond Law Review, Vol. 24, Issue 1.

55. Varottil, U., 2017, The Scheme of Arrangement as a Debt Restructuring Tool in India: Problems and Prospects, European Company and Financial Law Review, Vol. 15, Issue 3.

56. Verrill, L., 2004, The R3 Regulation Survey, Recovery, Autumn issue.

57. Warren, E., Westbrook, J. L., 2009, The Success of Chapter 11: A Challenge to the Critics, Michigan Law Review, Vol. 107, Issue 4.

58. Weir, T., 1996, Taking for Granted: The Ramifications of Nemo Dat, Current Legal Problems, Vol. 49, No. 1.

59. Weston, K., 2013, Lifeblood, Liquidity, and Cash Transfusions: Beyond Metaphor in the Cultural Study of Finance, Journal of the Royal Anthropological Institute, Vol. 19, No. 1.

60. Wood, P., 2003, Passu Clauses-What Do They Mean?, Butterworths Journal of International Banking \& Financial Law, Vol. 18, No. 10.

61. Worthington, S., 1996, Proprietary Interests in Commercial Transactions, Oxford, Clarendon Press.

62. Ziegel, J. S., The Privately Appointed Receiver and the Enforcement of Security Interests: Anomaly or Superior Solution?, in: Ziegel, J. S., (ed.) 1994, Current Developments in International and Comparative Corporate Insolvency Law, Oxford, Clarendon Press.

63. Zwieten, K., 2015, Corporate Rescue in India: The Influence of the Courts, Journal of Corporate Law Studies, Vol. 15, Issue 1.

64. Zwieten, K., 2018, Director Liability in Insolvency and Its Vicinity, Oxford Journal of Legal Studies, Vol. 38, No. 2. 


\section{Legislative Sources}

1. Companies Act 2013, India.

2. Hire Purchase Act 1972, India.

3. Indian Contract Act, 1872.

4. Insolvency Act 1986, UK.

5. Insolvency and Bankruptcy Code, 2016, India.

6. Registration Act, 1908, India.

7. SARFAESI Act 2002, India.

8. The Report of the Review Committee on Insolvency Law and Practice (Cmnd 8558, 1982), UK.

9. Transfer of Property Act 1882, India.

10. Uniform Commercial Code, United States.

11. White Paper Insolvency: A Second Chance (Cmnd 5234, July 2001), UK.

\section{Case Law}

1. Agnew v. Commissioner of Inland Revenue [2001] 2 AC 710.

2. Benedict v. Ratner (1925) 268 US 354.

3. Browne-Wilkinson V-C in Re Paramount Airways Ltd 2 [1990] BCC 130.

4. Chow Yoong Hong v. Choong Fah Rubber Manufactory [1962] AC 209.

5. Edwards v. Flightline Ltd [2003] 1 WLR at 1200.

6. Illington v. Houldsworth [1904] AC 355.

7. In Re BCCI (No. 8) [1998] AC 214.

8. Madura Coats Limited v. Modi Rubber Ltd (2016) Comp. Cas. 261 (SC).

9. Mirror Group Newspapers plc v. Maxwell [1998] BCC 324.

10. Pioneer Urban Land and Infrastructure Limited v. Union of India (2019), Writ Petition (Civil) No. 43/2019.

11. Re Brightlife Ltd [1987] Ch 200.

12. Re Coslett (Contractors) Ltd [1998] Ch 495.

13. Re Independent Insurance Co Ltd (No 2) [2003] EWHC 51 (Ch).

14. Re Independent Insurance Co Ltd [2002] 2 BCLC 709.

15. Re Spectrum Plus Ltd [2005] UKHL 41.

16. Re T\& N Ltd and Others [2006] 3 All ER 697.

17. Re Yorkshire Woolcombers Association Ltd [1903] 2 Ch.

18. Salomon v. A. Salomon \& Co. Ltd [1897] AC 22.

19. Siebe Gorman v. Barclays Bank [1979] 2 Lloyd's Rep. 142.

20. Smith v. Bridgend County Borough Council [2002] 1 AC 336.

21. Solomons and Defty v. Cheal, Huggins and Coster [2011] EWHC 2543 (Ch).

22. Tata Motors Ltd. v. Pharmaceutical Products of India Ltd (2008) 114 Comp. Cas. 178 (SC). 
23. Twyne's Case [1601] 76 ER 809.

24. Zartman v. First National Bank (1907) 189 NY 267.

\section{INTERNET SOURCES}

1. Das, S., 2018, IBBI Looks to Rationalize Fees Structure, The Economic Times, (https://economictimes.indiatimes.com/markets/stocks/news/ibbi-looks-to-rationalise-fees-structure/articleshow/63584369.cms?from=mdr, 10. 7. 2020).

2. Dutt, I., 2019, IBC Resolutions Exceed New Time Limit of 330 Days Prescribed by Government, Business Standard, (https://www.business-standard.com/article/ companies/ibc-resolutions-exceed-new-time-limit-of-330-days-prescribed-bygovt-119102800661_1.html, 12. 8. 2020).

3. Ministry of Finance, Government of India, Interim Report of the Bankruptcy Law Reform Committee, 2015, p. 77, (http://finmin.nic.in/reports/Interim_Report_ BLRC.pdf, 12. 9. 2020).

4. Munerry, J., 2020, The Difference Between Secured and Unsecured Creditors, Begbies Traynor (https://www.begbies-traynorgroup.com/articles/director-advice/ the-difference-between-secured-and-unsecured-creditors).

5. Press Trust of India, 2018, India has third highest number of family-owned businesses in the world, Business Standard. Available (https://www.business-standard. com/article/current-affairs/india-has-third-highest-number-of-family-ownedbusinesses-in-the-world-118091400409_1.html, 14. 9. 2020).

6. Review of the Corporate Insolvency Framework: A Consultation on Options for Reform, 2016, The Insolvency Service (https://assets.publishing.service.gov.uk/ government/uploads/system/uploads/attachment_data/file/525523/A_Review_ of_the_Corporate_Insolvency_Framework.pdf).

7. Sengupta, R., Sharma, A., and Thomas, S., 2016, Evolution of the Insolvency Framework For Non-Financial Firms in India (http://www.igidr.ac.in/pdf/publication/WP-2016-018.pdf, 10. 9. 2020).

8. SME Sector in India: Statistics, Trends and Reports. (https://evoma.com/business-centre/sme-sector-in-india-statistics-trends-reports/\#: :text=Number $\% 20$ of\%20SMEs\%20in\%20India,\%2C\%2040\%25\%20of\%20India's\%20workforce. 12. 9. 2020).

9. The Central Registry of Securitisation Asset Reconstruction and Security Interest of India (https://www.cersai.org.in/).

10. The World Bank Data, 2019, (https://data.worldbank.org/indicator/SP.POP.TOTL?locations=IN, 12. 9. 2020).

11. US Courts, Chapter 11 - Bankruptcy Basics, (https://www.uscourts.gov/services-forms/bankruptcy/bankruptcy-basics/chapter-11-bankruptcy-basics, 12.06 . 2020).

12. Vivek, K., 2020, A Few Hits \& Some Misses, That's The IBC Track Record, Mint, (https://www.livemint.com/news/india/a-few-hits-some-misses-that-s-the-ibctrack-record-11582474699506.html, 10.0 8. 2020).

13. World Bank Ease of Doing Business Report, 2020 (https://www.doingbusiness. org/en/rankings). 
Williams C. Iheme, Remedying the Defects in India's Credit and Insolvency Frameworks...

\title{
OTKLANJANJE NEDOSTATAKA U INDIJSKIM KREDITNIM I STEČAJNIM OKVIRIMA PRILAGOĐENIM REŠENJIMA IZ ANGLOAMERIČKE PRAVNIČKE LITERATURE
}

\author{
Williams C. Iheme
}

\section{REZIME}

Zakon koji uređuje kreditne transakcije u Indiji je izdeljen čime stvara poteškoće ugovornim stranama da koriste kredit. Sveukupni efekat ovakvog rešenja se već oseća u niskom rangu zemlje na indikatoru „pristupa kreditu“ u Izveštaju Svetske banke za 2020. godinu o lakoći obavljanja poslovanja (Doing business report). Zakon o stečaju i likvidaciji iz 2016. godine (Kodeks), koji je gotovo kopija engleskog Zakona o stečaju iz 1986. godine, ima određene nedostatke koji su nespojivi sa lokalnim stanjem stvari u pogledu pristupa kreditima i reorganizaciji preduzeća. Neki od ovih nedostataka proizlaze iz nepravedne kategorizacije poverilaca $\mathrm{u}$ "operativne“ i „finansijske“ tipove u Kodeksu i posledične zabune koja je zabeležena u slučaju Vrhovnog suda „Domaći kupci“ iz 2019. godine. Začuđujuće, finansijski poverioci uživaju povoljniji tretman propisan Kodeksom u odnosu na operativne poverioce, uključujući pravo na konstituisanje odbora poverilaca u glasanju i potvrđivanju planova reorganizacije. Proces rešavanja nelikvidnosti predviđen Kodeksom nije kompatibilan sa činjenicom da preko $90 \%$ kompanija koje posluju u Indiji spadaju u mala i srednja preduzeća, odnosno porodična preduzeća. Smatra se da će znatni finansijski teret procesa reorganizacije postepeno uništiti ova mala i srednja preduzeća i prouzrokovati nagli rast stope nezaposlenosti. U radu se ukazuje na brojne nedostatke u indijskim kreditnim i stečajnim sistemima i predlaže se uvođenje određenih rešenja iz engleskog sistema, kao i američkog poglavlja 11 i člana 9. Jedinstvenog trgovinskog zakona.

U radu se daje niz preporuka koje mogu biti od pomoći u otklanjanju identifikovanih nedostataka. Prvo, razne sigurnosne institute rasute $\mathrm{u}$ različitim delovima pravnog okvira i propisa, npr. SARFESI zakon, Zakon o kompanijama, Zakon o kupovini najma, indijski zakon o obligacijama, zakon o uslovnoj prodaji i najmu opreme, primenjivim pravilima common law-a, i druge, trebalo bi podvesti pod jedinstveni funkcionalni pristup kao u članu 9. američkog Jedinstvenog trgovinskog zakona koji se primenjuje na obezbeđene kreditne transakcije. Tako da bez obzira na to kako ugovorne strane kvalifikuju transakciju, član 9. bi se primenjivao ako je njihovim sporazumom predviđeno obezbeđivanje otplate kredita ličnom imovinom dužnika. Ako se usvoji jedinstveni funkcionalni pristup, on će 
poboljšati predvidljivost, smanjiti složenost i troškove pristupa kreditima i pozitivno uticati na lakoću poslovanja u Indiji.

Drugo, rad preporučuje vraćanje Dobrovoljnog aranžmana kompanije, koji je nekada bio deo indijskog zakona prema ukinutom Zakonu o kompanijama iz 1956. godine. S obzirom na jedinstvene uslove u Indiji, kako se tvrdi u radu, Dobrovoljni aranžman kompanije, koji je funkcionalni ekvivalent američkoj povelji 11. DIP o reorganizaciji, Indiji više odgovara zbog nižih troškova reorganizacije i činjenice da je većina indijskih kompanija mala i u porodičnom vlasništvu, odnosno da oni generalno ne mogu da priušte velike troškove administracije i postupka reorganizacije.

Treće, proizilazi iz druge preporuke, budući da je trenutni postupak reorganizacije prototip engleskog rešenja, koji predviđa rad lica u postupku reorganizacije koji u stvarnosti nisu profesionalci u pravom smislu, ili čija stručnost teško može biti relevantna za spasavanje određenih vrsta preduzeća. Na primer, dva glavna tipa zanimanja predviđena Pravilnikom o licima zaposlenim u postupku stečaja jesu pravnici i računovođe koji predstavljaju profesije orijentisane na usluge, pri čemu iskustvo stečeno iz advokatske ili računovodstvene prakse teško da može biti korisno za postupak reorganizacije kompanija iz IT sektora, supermarketa, prehrambenih prodavnica, građevinskih kompanija i drugih vrsta preduzeća koja se bave proizvodnjom sa složenim poslovnim modelima. Ne postoji zatvorena lista tipova preduzeća koja se mogu pojaviti u budućnosti. Stoga je ograničavanje profesija iz kojih dolaze zaposleni u procesu reorganizacije ozbiljna greška i izgleda kao favorizovanje interesa pravnika i računovođa nad ekonomskim interesima pojedinaca i preduzeća u Indiji. Još jednom, ovo nameće pitanja o regulatornom položaju IBC 2016 i pripadajućim propisima IRP. Naime, trebalo bi ponovo uključiti u indijski sistem stečaja Dobrovoljni aranžman kompanija koji odražava američki DIP model iz poglavlja 11.

Četvrto, i poslednje, kategorizacija poverilaca u finansijske i operativne poverioce, sa neprimerenim preferencijalnim tretmanima za prve, štetna je za ukupnu efikasnost i poverenje u kreditni sistem i sistem stečaja. Većina poverilaca obično spada u kategoriju „operativnih“, a prema IBC 2016, između ostalih nedostataka, oni nisu kvalifikovani za ulazak u odbor poverilaca gde bi imali pravo glasa za predloženi plan reorganizacije koji utiče na njihova prava u pogledu obezbeđenja. Takva mogućnost predviđa se u engleskom i američkom sistemu gde se pravo glasa o predloženom planu reorganizacije daje svim poveriocima. Mogućnost započinjanja postupka reorganizacije preduzeća nakon dospeća duga bez prethodnog formalnog zahteva (što se zahteva od operativnih poverilaca), pokazuje da Zakon o stečaju i likvidaciji iz 2016. godine nije objek- 
tivan i veran filozofiji korporativnog spasavanja. Postoji hitna potreba za reformom sa svešću o pomenutim pitanjima. U svakom slučaju, pomenuti nedostaci predstavljaju nužne razloge za indijski parlament da preispita i reformiše Zakon o stečaju i likvidaciji.

Ključne reči: kredit, obezbeđenje, dug, kolateral, reorganizacija, stečaj, poverilac, dužnik, pravna reforma.

Article History:

Received: 14 September 2020

Accepted: 25 November 2020 